\title{
CMV pp65 Peptide-pulsed Autologous Dendritic Cell Vaccine
}

National Cancer Institute

\section{Source}

National Cancer Institute. CMV pp65 Peptide-pulsed Autologous Dendritic Cell Vaccine.

NCI Thesaurus. Code C116740.

A cell-based cancer vaccine composed of autologous dendritic cells (DCs) pulsed with the human cytomegalovirus (CMV) phosphoprotein pp65, with potential immunostimulatory and antineoplastic activities. Upon administration, the CMV pp65 peptide-pulsed autologous DC vaccine exposes the immune system to the CMV pp65 peptide, which may result in a cytotoxic T-lymphocyte $(C T L)$ response against CMV pp65-expressing tumor cells leading to cell lysis. The CMV pp65 protein, also called the $65 \mathrm{kDa}$ lower matrix phosphoprotein, is the primary component of the enveloped subviral particle of CMV and is expressed in certain tumor types, such as glioblastoma. 